\title{
Forum
}

\section{Navigation Lights}

\author{
Captain B. D. George
}

IT is natural that present attitudes towards safety at sea and collision avoidance should reflect a justifiable preoccupation with electronics in meeting the exigencies of marine traffic congestion and collision hazards. Despite the frequency with which marine casualties occur during darkness and in conditions of poor visibility there is a tendency to minimize the positive, if modest, contribution of efficient and distinctive ships' navigation lights towards safety at sea in these circumstances.

It is equally surprising, considering the economics of ship operation, that more attention has not been given to ship lighting systems, relating output efficiency, current consumption and statutory visibility ranges. Long burning lights on unmanned tows provide an example, where minimal current consumption commensurate with statutory requirements will measurably reduce installation costs. This paper therefore attempts to collate the relevant criteria, including the background to present day requirements in comparison with the standards necessary to comply with the new International Collision Regulations shortly coming into force.

The present regulations are based on the findings of the 1922 Committee on Ships' Navigation Lights, which established that a light source of candle power 1.6 was visible in darkness under clear conditions at a distance of two miles. From this, direct application of the inverse square law yielded the results shown in Table I.

TABLE I. Theoretrcal RANGes of Lights

\begin{tabular}{l|c|c|c|c}
\hline Maximum range in nautical miles & $\mathrm{I}$ & 2 & 3 & 5 \\
\hline Effective candle power required & 0.4 & 1.6 & 3.6 & 10 \\
\hline
\end{tabular}

To compensate for the limited luminous intensity provided by paraffin oil lamps it was common to use drum type dioptric lenses to increase the intensity in the horizontal plane. Furthermore, side lights and lights on vessels not under command had to be coloured. The values in Table I had therefore to be modified by two factors and the figures in Table II are based on the following assumptions:

(i) the average drum type dioptric lens used for ships' navigation lights produces a beam intensity of twice the source intensity. This is a generalization and may be pessimistic since typical factors are closer to three times.

(ii) The typical transmission factor for a coloured filter has been taken as Io per cent, which is also conservative by present day standards as factors of 20 per cent for red and i 5 per cent for green are realizable. 
TABle II. MODIFIED estimate OF RANGes

\begin{tabular}{l|c|c}
\hline & $\begin{array}{c}\text { Side lights and 'not under } \\
\text { command' }\end{array}$ & $\begin{array}{c}\text { Masthead } \\
\text { lights }\end{array}$ \\
\hline Theoretical minimum range (n.m.) & 2 & 5 \\
\hline Source candle power & 12 & 12 \\
\hline Effective candle power & $2 \cdot 4$ & 24 \\
\hline
\end{tabular}

For electric lights the committee made the following suggestions :

(i) The use of a dioptric lens, essential for oil lights, although not forbidden was deprecated on the ground that misalignment of the geometric centres of the lens and the illuminating source could adversely affect light propagation.

(ii) Squirrel cage flaments were recommended for light bulbs.

(iii) The voltages considered were 110 and 220.

(iv) A drop of 5 volts off a 110 -volt supply might reduce the efficiency of a light bulb by as much as 20 to $3 \circ$ per cent.

(v) Removable shades for coloured lights were preferable to coloured lenses.

Subsequent regulations made the use of dioptric lenses optional and it was suggested that 40 -watt bulbs conforming with BS 555 would prove adequate in practice.

Figures 1 and 2 show that masthead light ranges of 4 to 54 miles would be reasonably possible using plain cylinders and dioptric lenses respectively, in conjunction with 40-watt designated navigation light bulbs, but up to $4 \frac{1}{2}$ and $5 \frac{1}{2}$ miles respectively when ordinary light bulbs were used (BS 555:1962). These

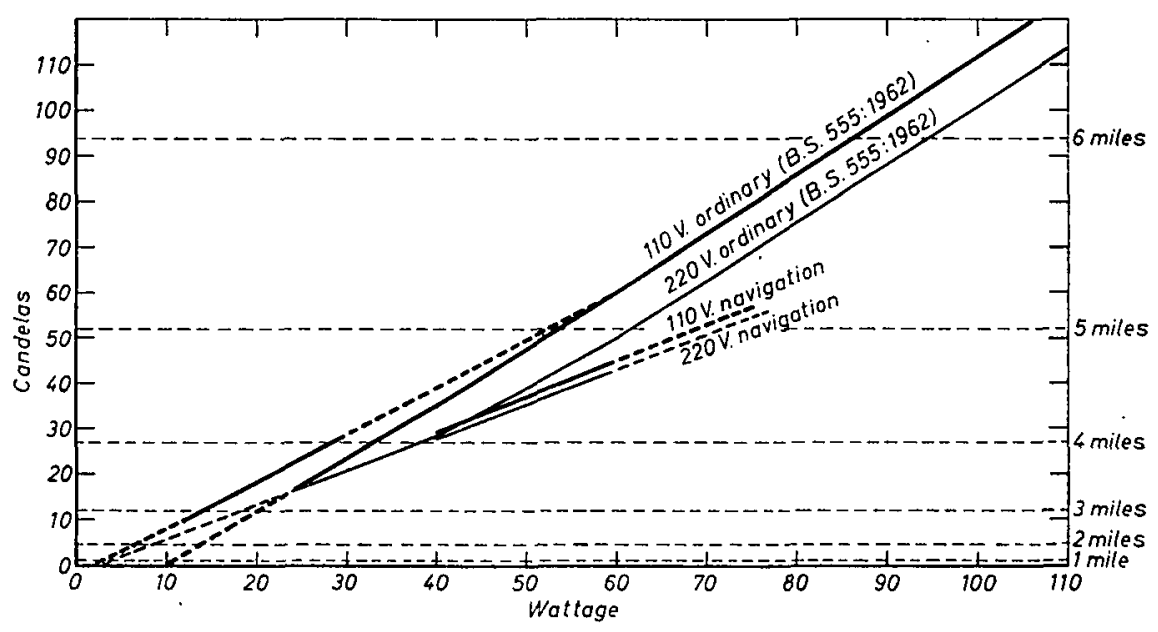

FIG. I 


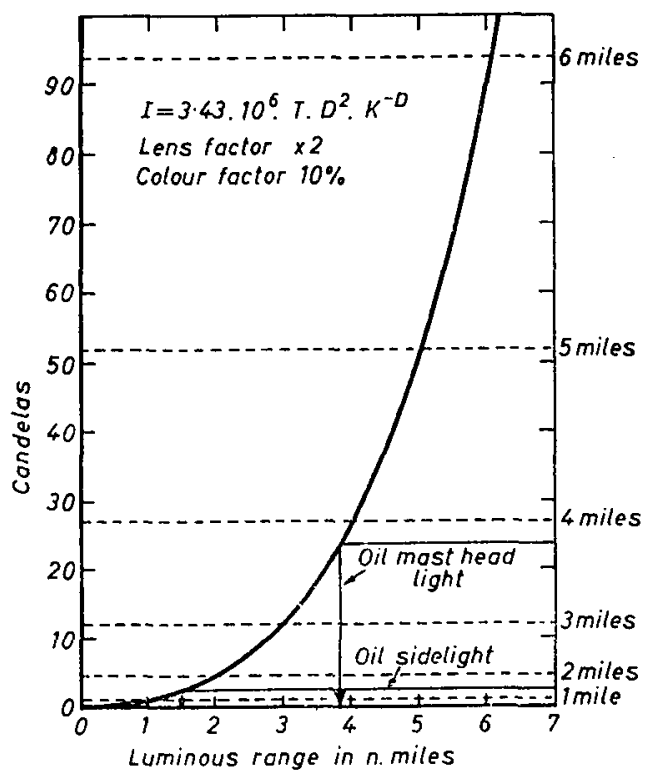

FIG. 2

ranges are calculated using modern methods which are less optimistic than the results presumably derived from the inverse square law. The dotted lines in Fig. i are extrapolations not supported by actual data. Table III shows the approximate relationship between wattage and mean spherical candle power. The corresponding values for mean horizontal candle power, relevant in the case of navigation lights, would be slightly greater than the quoted values.

TABLe III. Wattage ANd CANDle POWer

\begin{tabular}{l|c|c|c|c|c}
\hline Watts & 25 & 40 & 60 & 75 & 100 \\
\hline Mean spherical candle power & 19 & 37 & 63 & 85 & 119 \\
\hline
\end{tabular}

Since 1967 candle power as a measure of the luminous intensity of a light has been superseded by the 'candela' (cd) which is defined as: 'The luminous intensity, in the perpendicular direction, of a surface of $1 / 600,000$ square metre of a full radiator at the temperature of freezing platinum under a pressure of 101,325 newtons per square metre' (BS 4727). The 'luminous efficacy' of a source is defined as the quotient of the luminous flux emitted by the power consumed, expressed as lumens per watt (BS 4727 ). Table IV shows the relationship between effective luminous intensity measured in candelas and luminous range, also the nature of their involvement in the classification of vessels in the new Collision Regulations. Their respective values are related in accordance with the following formula :

$$
I=3.43 \times 10^{6} \times T \times D^{2} K^{-D}
$$


where $I=$ intensity in candelas

$T=$ threshold factor $\left(2 \times 10^{-7}\right.$ lux $)$

$D=$ range of visibility (in nautical miles)

$K=$ atmospheric transmissivity (per nautical mile)

Table IV. Light requirements and the new Collision Regulations

\begin{tabular}{|c|c|c|}
\hline Vessels applicable & $\begin{array}{c}\text { Required } \\
\text { luminous } \\
\text { range (n.m.) }\end{array}$ & $\begin{array}{c}\text { Required } \\
\text { effective } \\
\text { luminous } \\
\text { intensity in } \\
\text { candelas } \\
\text { (when } K=0.8 \text { ) }\end{array}$ \\
\hline Side lights for vessels under $12 \mathrm{~m}$. & $\mathbf{r}$ & 0.86 \\
\hline $\begin{array}{l}\text { Masthead lights for vessels under } 12 \mathrm{~m} \text {, side lights } \\
\text { for vessels I } 2 \text { to } 50 \mathrm{~m} \text { stern lights and all } \\
\text { around lights for vessels under } 50 \mathrm{~m}\end{array}$ & 2 & $4 \cdot 3$ \\
\hline $\begin{array}{l}\text { Side lights, stern lights and all around lights for } \\
\text { vessels } 50 \mathrm{~m} \text { or over. Masthead lights for vessels } \\
\text { 1 } 2-20 \mathrm{~m}\end{array}$ & 3 & I 2 \\
\hline Masthead lights for vessels $20-50 \mathrm{~m}$ & 5 & $5^{2}$ \\
\hline Masthead lights for vessels $50 \mathrm{~m}$ or over & 6 & 94 \\
\hline
\end{tabular}

A comparison of the values given in Tables I and II confirms that earlier estimates of the relationship between source intensity of illumination and luminous range were optimistic by present-day standards. Thus from Table I and the inverse square law the source intensity of illumination for 5 miles $=\mathrm{I} \cdot 6 \times 5^{2} / 2^{2}=$ ro cd. Using Eqn. (I) and Table II, $4.3 \times 5^{2} / 2^{2} \times(0.8)^{-3}=52.5 \mathrm{~cd}$.

Again, reference to Fig. 2 shows that a 12 cd source in an oil masthead lantern equipped with a dioptric lens would probably be visible at about $3 \frac{3}{4}$ miles, not 5 miles as intended by Rule 2 of the 1960 International Regulations. This represents an approximate loss of 25 per cent in luminous range. The true cause of the difference between former and present-day assessments for luminous range lies in the value of $K^{-D}$ in Eqn. (1), which represents the loss due to the scattering of light by water droplets in the atmosphere (e.g. mist and fog). There is thus a direct relationship between the value of $K$ and the meteorological visibility. The inverse square law which was formerly used for this kind of calculation is accurate only under conditions of good visibility, say, 20 miles or so.

Table $\mathrm{V}$ attempts to relate luminous intensity in candelas with wattage and voltage, as derived from Fig. r. This graph has been drawn using British Standard Specifications nominal values for intensities of source illumination, expressed in candelas, corresponding to the appropriate wattages of 'general service' bulbs. Where specific information has been available for designated navigation light bulbs this has been added separately and serves to indicate the apparently greater 
intensities of the ordinary bulbs (BS 555:62). It is assumed that a dioptric lens produces a magnification of $\times 2$ and that the transmission factor for a colour filter is ro per cent. Unfortunately no assessment of 12 -volt circuity is possible, due to insufficient published data despite the obvious economic advantages in its shipboard use.

Table V. Characteristics for electric navigation lights

\begin{tabular}{|c|c|c|c|c|c|c|c|c|c|}
\hline & \multicolumn{2}{|c|}{$\begin{array}{l}\text { Luminous intensity } \\
\text { (cd) }\end{array}$} & \multicolumn{3}{|c|}{ Wattage } & \multirow{3}{*}{$\begin{array}{l}\text { Visual } \\
\text { range } \\
\text { (n.m.) }\end{array}$} & \multicolumn{3}{|c|}{$\begin{array}{l}\text { Maximum* } \\
\text { range }\end{array}$} \\
\hline & \multirow[t]{2}{*}{ Source } & \multirow{2}{*}{$\begin{array}{c}\text { Source/ } \\
\text { lens/filter } \\
\text { combination }\end{array}$} & \multirow[t]{2}{*}{$24 \mathrm{~V}$} & \multirow[t]{2}{*}{$110 \mathrm{~V}$} & \multirow[t]{2}{*}{$220 \mathrm{~V}$} & & & & \\
\hline & & & & & & & Red & White & Green \\
\hline $\begin{array}{l}\text { With dioptric lens } \\
\text { Side lights } \\
\text { and 'not } \\
\text { under } \\
\text { command' }\end{array}$ & $\begin{array}{r}4 \cdot 5 \\
21 \cdot 5 \\
60 \cdot 0\end{array}$ & $\begin{array}{r}0.9 \\
4.3 \\
12.0\end{array}$ & $\begin{array}{r}7 \\
23 \\
60\end{array}$ & $\begin{array}{l}14 \\
27 \\
60\end{array}$ & $\begin{array}{l}-\overline{31} \\
68\end{array}$ & $\begin{array}{l}1 \\
2 \\
3\end{array}$ & $\begin{array}{l}1 \cdot 6 \\
3 \cdot 1 \\
4 \cdot 3\end{array}$ & & $\begin{array}{l}1.4 \\
2.8 \\
\\
3 \cdot 9\end{array}$ \\
\hline $\begin{array}{l}\text { Masthead } \\
\text { lights }\end{array}$ & $\begin{array}{r}2 \cdot 2 \\
6 \cdot 0 \\
26 \cdot 0 \\
47 \cdot 0\end{array}$ & $\begin{array}{r}4 \cdot 3 \\
12 \cdot 0 \\
52 \cdot 0 \\
94 \cdot 0\end{array}$ & $\begin{array}{r}5 \\
7 \\
27 \\
47\end{array}$ & $\begin{array}{l}12 \\
15 \\
31 \\
50\end{array}$ & $\begin{array}{l}- \\
- \\
38 \\
57\end{array}$ & $\begin{array}{l}2 \\
3 \\
5 \\
6\end{array}$ & & $\begin{array}{l}2.4 \\
3.4 \\
5.7 \\
6.8\end{array}$ & \\
\hline Stern lights & $\begin{array}{l}6 \cdot 0 \\
2 \cdot 2\end{array}$ & $\begin{array}{r}12 \cdot 0 \\
4 \cdot 3\end{array}$ & $\begin{array}{l}8 \\
5\end{array}$ & $\begin{array}{l}15 \\
12\end{array}$ & - & $\begin{array}{l}3 \\
2\end{array}$ & & $\begin{array}{l}3 \cdot 4 \\
2 \cdot 4\end{array}$ & \\
\hline $\begin{array}{l}\text { With plain } \\
\text { cylinder } \\
\text { Side lights } \\
\text { and 'not } \\
\text { under } \\
\text { command' }\end{array}$ & $\begin{array}{r}9.0 \\
43.0 \\
120.0\end{array}$ & $\begin{array}{r}0.9 \\
4.3 \\
12 \cdot 0\end{array}$ & $\begin{array}{l}11 \\
44 \\
-\end{array}$ & $\begin{array}{r}18 \\
46 \\
106\end{array}$ & $\begin{array}{r}-5 \\
54 \\
115\end{array}$ & $\begin{array}{l}1 \\
2 \\
3\end{array}$ & $\begin{array}{l}1 \cdot 4 \\
2.7 \\
3.8\end{array}$ & & $\begin{array}{l}1 \cdot 2 \\
2 \cdot 4 \\
3 \cdot 4\end{array}$ \\
\hline $\begin{array}{l}\text { Masthead } \\
\text { lights }\end{array}$ & $\begin{array}{r}4 \cdot 3 \\
12 \cdot 0 \\
52 \cdot 0 \\
94 \cdot 0\end{array}$ & $\begin{array}{r}4 \cdot 3 \\
12 \cdot 0 \\
52 \cdot 0 \\
94 \cdot 0\end{array}$ & $\begin{array}{r}6 \\
14 \\
53 \\
-\end{array}$ & $\begin{array}{l}14 \\
20 \\
54 \\
86\end{array}$ & $\begin{array}{l}- \\
18 \\
62 \\
95\end{array}$ & $\begin{array}{l}2 \\
3 \\
5 \\
6\end{array}$ & & & \\
\hline Stern lights & $\begin{array}{r}4 \cdot 3 \\
12 \cdot 0\end{array}$ & $\begin{array}{r}4 \cdot 3 \\
12 \cdot 0\end{array}$ & $\begin{array}{r}6 \\
14\end{array}$ & $\begin{array}{l}14 \\
20\end{array}$ & $\overline{18}$ & $\begin{array}{l}2 \\
3\end{array}$ & & & \\
\hline
\end{tabular}

* Maximum range is based on transmission factors of 20 per cent for red, 15 per cent for green, in conjunction with a lens factor of 3 . The luminous range is deduced from Fig. 2.

In the past, oil navigation lights have been kept as a provision against electrical failure, their accepted intensity of source illumination is equivalent to $12 \mathrm{~cd}$. This is related to luminous range in Table VI, which has been calculated from Eqn. (1). 
TABle VI. Luminous RANGE OF OIL LAMPS

\begin{tabular}{|c|c|c|c|c|}
\hline & \multicolumn{2}{|c|}{$\begin{array}{l}\text { Luminous intensity } \\
\text { (cd) }\end{array}$} & \multirow{2}{*}{$\begin{array}{c}\text { Probable } \\
\text { luminous } \\
\text { range } \\
\text { (n.m.) }\end{array}$} & \\
\hline & Source & $\begin{array}{c}\text { Source/ } \\
\text { lens/filter } \\
\text { combination }\end{array}$ & & \\
\hline $\begin{array}{l}\text { Side lights and 'not } \\
\text { under command' } \\
\text { Masthead lights }\end{array}$ & 12 & $\begin{array}{r}2 \cdot 4 \\
24 \cdot 0\end{array}$ & $\begin{array}{l}1 \frac{1}{2} \\
3 \frac{3}{4}\end{array}$ & $\begin{array}{c}\text { Based on a lens factor of } \times 2 \text { and } \\
\text { transmission factor of } 10 \%\end{array}$ \\
\hline $\begin{array}{l}\text { Red lights } \\
\text { Green lights } \\
\text { White lights }\end{array}$ & $\begin{array}{l}12 \\
12 \\
12\end{array}$ & $\begin{array}{r}7 \cdot 2 \\
5 \cdot 4 \\
36 \cdot 0\end{array}$ & $\begin{array}{l}2 \frac{1}{2} \\
2 \frac{1}{4} \\
4 \frac{1}{2}\end{array}$ & $\begin{array}{l}\text { Based on a lens factor of } \times 3 \text { and } \\
\text { filter transmission factor of } \\
20 \% \text { for red and } 15 \% \text { for } \\
\text { green }\end{array}$ \\
\hline
\end{tabular}

The first two items in Table VI show that such lights are apparently only suitable for the side lights of vessels up to 12 metres in length, and for stern or anchor lights for vessels of any length, under the new Collision Regulations. The other items apparently extend the use of coloured oil lights to vessels up to 50 metres in length, except as masthead lights for vessels 20 to 50 metres in length which are required to have a range of 5 miles. The alternative to oil lights would presumably be some form of battery operated electric light, in which case Table $\mathrm{V}$ provides some guidance as to the factors involved for voltages down to $24 \mathrm{~V}$.

\section{A Tabular Method for Star-Sight Reduction}

\section{Nastro and A. Russo}

IN a recent paper in this Journal the Director of the Royal Institute of Navigation describes some methods of navigating small vessels; he rightly includes classical astronomical navigation and describes some speedy and well-known methods of solution. In spite of the availability of such tables and mechanical devices the solution is not within everybody's reach because nautical ephemerides are always necessary; convenient tables are the Sight Reduction Tables for Air Navigation (A.P. 3270 ) from which the elements for tracing out the lines of position through the intercept method can easily be extracted. The simpler tables here proposed present the following advantages :

(i) the ephemeris is not required

(ii) the observed sextant altitude need not be corrected for refraction and dip.

Our tables are, however, valid for a limited sea area only; they are in fact ephemerides in which the altitude (corrected for astronomical refraction) and the azimuth of a few selected stars are given for an auxiliary point (the centre 